


\title{
PRODUKSI DAN KUALITAS JERAMI JAGUNG SEBAGAI PAKAN TERNAK SAPI DI KABUPATEN MINAHASA SELATAN
}

\section{THE PRODUCTION AND THE QUALITY OF CORN STRAW AS CATTLE FEED IN SOUTH MINAHASA REGENCY}

\author{
Ronald Hendro Paath1), David A. Kaligis²), dan Charles L. Kaunang2) \\ 1)Dinas Pertanian dan Peternakan Kabupaten Minahasa Selatan \\ 2)Fakultas Peternakan UNSRAT Manado
}

\begin{abstract}
The purpose of this study was to calculate the productivity of corn straw, and to measure the quality of corn straw as cattle feed at different altitude conditions, at South Minahasa regency. The research was conducted in May through September 2011, starting from collection of secondary data, primary data, on-site observations, corn straw sampling, and shipment of samples to be analyzed in Ruminant Animal Nutrition Laboratory and Livestock Chemistry, Faculty of Animal Science University of Padjadjaran Bandung. The results of the t-test analysis showed that there was a very significant difference between the protein, Neutral Detergent Fiber, Acid Detergent Fiber, and the production of corn straw in the lowlands and the highlands. Where in highlands, the production of corn straw and hay protein content was higher than in the lowlands, in lowland area was a reverse. A component of the Acid Detergent Fiber (ADF) and Neutral Detergent Fiber (NDF) was lower in the highlands than in lowlands. Corn straw can also be utilized as an animal feed based on Total Digestible Nutrient (TDN). Total Digestible Nutrient in West Amurang district was 2,204,785 kg (2,204.8 tons), while in Kumelembuai district, its was found only $877,533 \mathrm{~kg}$ (877.5 tons). It is concluded in this research that there were differences in the production of corn straw, protein, ADF, and NDF between lowland and upland areas. The protein content and the corn straw production as well as the content of ADF and NDF were higher in highland areas.
\end{abstract}

Keywords : Corn straw, NDF, ADF

\begin{abstract}
ABSTRAK
Tujuan penelitian untuk menghitung produktivitas jerami jagung dan tuntuk mengukur kualitas jerami jagung sebagai pakan ternak sapi pada kondisi ketinggian berbeda di Kabupaten Minahasa Selatan. Penelitian berlangsung sejak bulan Mei sampai dengan September 2011, mulai dari pengambilan data sekunder, data primer, pengamatan di lokasi, pengambilan sampel jerami jagung dan pengiriman sampel untuk dianalisis di Laboratorium Nutrisi Ternak Ruminansia dan Kimia Makanan Ternak Fakultas Peternakan Universitas Padjajaran Bandung. Hasil analisis uji t menunjukkan bahwa terdapat perbedaan yang sangat nyata protein, Neutral Detergent Fiber (NDF), Acid Detergent Fiber (ADF), dan produksi jerami jagung di dataran rendah dan dataran tinggi, di mana di daerah dataran tinggi produksi jerami jagung dan kandungan proteinnya lebih tinggi daripada di dataran rendah, tetapi untuk komponen ADF dan NDF lebih rendah di dataran tinggi daripada di daerah dataran rendah. Jerami jagung juga dapat memberikan kontribusi sebagai pakan ternak dilihat dari Total Digestible Nutrien (TDN) untuk Kecamatan Amurang Barat sebesar $2.204 .785 \mathrm{~kg}$ (2,204.8 ton) TDN, sedangkan di Kecamatan Kumelembuai adalah sebesar $877.533 \mathrm{~kg}$ (877,5 ton) TDN. Hasil penelitian disimpulkan bahwa ada perbedaan produksi jerami jagung, kandungan protein, ADF, dan NDF antara daerah dataran rendah dan daerah dataran tinggi. Kandungan protein dan produksi jerami jagung lebih baik di dataran tinggi, sedangkan dilihat dari kandungan ADF dan NDF masih lebih baik di dataran rendah.

Kata kunci: Jerami jagung, NDF, ADF
\end{abstract}

Eugenia Volume 18 No. 1 April 2012 


\section{PENDAHULUAN}

Percepatan sektor pertanian yang meliputi perluasan areal tanaman pangan merupakan bagian dari program pemerintah dalam rangka menunjang pembangunan agribisnis pertanian guna peningkatan ekonomi kerakyatan sebagai penyanggah utama sistem perekonomian nasional. Sejalan dengan perluasan tanaman pangan maka jerami jagung mempunyai potensi yang sangat besar untuk memenuhi kebutuhan pakan hijaun.

Jerami jagung banyak digunakan peternak daerah lahan kering sebagai pengganti rumput, terutama pada musim kemarau. Ketersediaan hijauan dengan populasi ternak ruminansia tidak berimbang berakibat semakin berkurangnya ketersediaan hijauan hampir sepanjang tahun, terutama di daerah padat ternak. Sumbangan limbah pertanian terutama jerami jagung sangat bermanfaat dalam mendukung perkembangan populasi ternak sapi.

Keadaan wilayah Kabupaten Minahasa Selatan sangat variatif dilihat dari aspek ketinggian tempat mulai dari pesisir pantai sampai pada dataran lebih tinggi seperti kawasan agropolitan Modoinding. Mengetahui bagaimana produksi dan kualitas jerami jagung sebagai pakan perlu dilakukan penelitian untuk mendapatkan informasi yang lengkap tentang pengaruh perbedaan ketinggian tempat terhadap produksi dan kualitas jerami jagung.

Produksi dan kualitas jerami jagung sebagai pakan ternak sapi akan sangat menentukan produktivitas ternak sapi. Kabupaten Minahasa Selatan yang memiliki ketinggian tempat yang bervariasi, diduga akan memberikan produksi dan kualitas jerami jagung yang juga bervariasi. Melalui penelitian ini diharapkan akan diketahui sejauh mana pengaruh ketinggian tempat terhadap produksi dan kualitas jerami jagung sebagai pakan ternak sapi.

Penelitian ini bertujuan untuk : 1) menghitung produktivitas jerami jagung sebagai pakan ternak sapi pada ketinggian tempat yang berbeda, di Kecamatan Amurang Barat dan Kecamatan Kumelembuai; 2) mengukur kualitas jerami jagung sebagai pakan ternak sapi pada ketinggian tempat yang berbeda, di Kecamatan Amurang Barat dan Kecamatan Kumelembuai.

\section{METODE PENELITIAN}

Penelitian ini dilaksanakan selama tiga bulan dari tanggal 26 Mei 2011 sampai dengan 26 Agustus 2011 berlokasi di dua kecamatan yang memiliki ketinggian tempat berbeda, yaitu: 1) Kecamatan Amurang Barat dengan ketinggian 0 $50 \mathrm{~m}$ dpl, yang meliputi Desa Teep, Kapitu dan Kawangkoan Bawah; 2) Kecamatan Kumelembuai dengan ketinggian $500-550 \mathrm{~m}$ dpl, yang meliputi Desa Kumelembuai, Kumelembuai atas dan Kumelembuai Dua.

Produktivitas jerami jagung segar dan konversi ke bahan kering. Kualitas jerami jagung: Protein Kasar dan Serat Kasar (NDF, ADF).

\section{Prosedur Penelitian}

Mengumpulkan data sekunder yang diperoleh dari pemerintah daerah setempat dan instansi yang terkait dengan penelitian ini, serta pengamatan langsung pada lokasi-lokasi lahan tanaman jagung; Berdasarkan data sekunder maka dipilih 3 (tiga) lokasi dari masing-masing desa/kelurahan untuk dijadikan lokasi pengamatan; Melakukan pengawalan penanaman jagung hibrida di seluruh lokasi penelitian yang diperlakukan sama (tanggal penanaman, varietas, jarak tanam, pemupukan dan tanggal pemotongan/pengambilan sampel); Pengambilan cuplikan/ubinan tanaman jagung menggunakan ubinan 2,5 x 2,5 m (6,25 $\left.\mathrm{m}^{2}\right)$ dengan 10 ulangan (Badan Pusat Statistik dan Departemen Pertanian RI, 2007), sampel dikumpulkan dan ditimbang bobot segarnya; Mengukur produktivitas jerami jagung per hektar, dilakukan dengan rumus:

$$
U b 1+U b 2+\ldots .+U b 10
$$

$\begin{array}{ll}\text { Rata-rata Ubinan } & = \\ \text { Luas Ubinan } & =2.5 \mathrm{~m} \times 2.5 \mathrm{~m}=6.25 \mathrm{~m}^{2}\end{array}$ $10000 \mathrm{~m}^{2}$

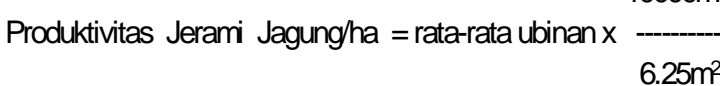
(Badan Pusat Statistik dan Departemen Pertanian $\mathrm{RI}, 2007$ ) 
Mengeringkan jerami jagung segar melalui panas sinar matahari selama 3 hari; Mengirim sampel Jerami Jagung untuk dianalisis di Laboratorium Nutrisi Ternak Ruminansia dan Kimia Makanan Ternak Fakultas Peternakan.

\section{Analisis Data}

Penelitian ini dilakukan dengan menggunakan metode survey. Penentuan lokasi penelitian digunakan cara Purposive Sampling (Singarimbun, 1982), berdasakan potensi wilayah dengan mengambil minimal $25 \%$ dari jumlah desa yang ada, dipilih tiga desa (Teep, Kapitu dan Kawangkoan Bawah) sebagai sampel dari 10 (sepuluh) desa di Kecamatan Amurang Barat dengan ketinggian tempat $0-50 \mathrm{~m}$ dpl dan tiga desa (Kumelembuai, Kumelembuai Atas dan Kumelembuai Dua) sebagai sampel dari 7 (tujuh) desa di Kecamatan Kumelembuai dengan ketinggian tempat $500-550 \mathrm{~m}$ dpl. Memperoleh informasi pemilikan lahan jagung tiap desa diambil 25 responden. Responden di tentukan berdasarkan luas pemilikan lahan di wilayah Kecamatan Amurang Barat dan Kecamatan Kumelembuai. Data yang digunakan dalam penelitian ini adalah data primer yang diperoleh dari wawancara, kuesioner dan pengambilan cuplikan/ubinan di lokasi tanaman jagung. Untuk data sekunder berupa luas lahan, produksi jagung dan populasi ternak sapi diperoleh dari Dinas Pertanian dan Peternakan Kabupaten Minahasa Selatan, Pemerintah setempat dan pengamatan langsung pada peternak sapi.

\section{HASIL DAN PEMBAHASAN}

\section{Produksi Berat Segar dan Bahan Kering Jerami Jagung}

Data hasil produksi jerami jagung dari kedua lokasi penelitian disajikan pada Tabel 1. Pada Tabel 1 menunjukkan bahwa hasil rata-rata produksi jerami jagung segar di kecamatan Amurang Barat $2949 \mathrm{Kg}$ ha ${ }^{1}$ nyata $(P<0,01)$ lebih rendah dibandingkan dengan hasil produksi jerami jagung segar di Kecamatan Kumelembuai sebesar $3675 \mathrm{Kg} \mathrm{ha}{ }^{1}$. Apabila asumsi $50 \%$ kandungan bahan kering dari jerami jagung segar (Preston, 2006; Umiyasih dan Wina, 2008) maka rataan produksi bahan kering di Kecamatan Amurang Barat diperoleh $1475 \mathrm{Kg}$ ha ${ }^{1}$, sedangkan di Kecamatan Kumelembuai mencapai 1873 kg ha ${ }^{1}$.

Tabel 1. Produksi Berat Segar dan Bahan Kering Jerami Jagung di Kecamatan Amurang Barat dan Kecamatan Kumelembuai

(Table 1. Production and Materials Fresh Weight Dry Corn Straw in the District and Sub-District of West Amurang Kumelembuai)

\begin{tabular}{|c|c|c|c|c|c|c|c|}
\hline \multirow[b]{2}{*}{ No. } & \multirow{2}{*}{$\begin{array}{l}\text { Lokasi } \\
\text { (Desa) }\end{array}$} & \multicolumn{2}{|c|}{ Kecamatan Amurang Barat } & \multirow[b]{2}{*}{ No. } & \multirow{2}{*}{$\begin{array}{l}\text { Lokasi } \\
\text { (Desa) }\end{array}$} & \multicolumn{2}{|c|}{$\begin{array}{l}\text { Kecamatan } \\
\text { Kumelembuai }\end{array}$} \\
\hline & & $\begin{array}{c}\text { Berat } \\
\text { Segar } \\
\left(\mathrm{kg} \mathrm{ha}^{1}\right)\end{array}$ & $\begin{array}{l}\text { Bahan } \\
\text { Kering } \\
\left(\mathrm{kg} \mathrm{ha}^{1}\right)\end{array}$ & & & $\begin{array}{c}\text { Berat } \\
\text { Segar } \\
\left(\mathrm{kg} \mathrm{ha}^{1}\right)\end{array}$ & $\begin{array}{c}\text { Bahan } \\
\text { Kering } \\
\left(\mathrm{kg} \mathrm{ha}^{1}\right)\end{array}$ \\
\hline 1. & Teep & 3344 & 1672 & 1. & Kumelembuai & 3472 & 1736 \\
\hline 2. & Kapitu & 2928 & 1464 & 2. & $\begin{array}{l}\text { Kumelembuai } \\
\text { Atas }\end{array}$ & 4048 & 2024 \\
\hline 3. & $\begin{array}{l}\text { Kawangkoan } \\
\text { Bawah }\end{array}$ & 2576 & 1288 & 3. & $\begin{array}{l}\text { Kumelembuai } \\
\text { Dua }\end{array}$ & 3504 & 1752 \\
\hline & $\bar{x}$ & 2949 & 1475 & & & 3675 & 1837 \\
\hline
\end{tabular}


Hasil bahan kering ini lebih rendah dibandingkan dengan 5-6 ton BK/ha seperti yang dilaporkan oleh Direktorat Budidaya Ternak Ruminansia (Umiyasih dan Wina, 2008).

Rendahnya produksi jerami jagung di Kecamatan Amurang Barat yang letaknya di dataran rendah mungkin terkait dengan suhu lingkungan yang relatif lebih tinggi $\left(25,4^{\circ} \mathrm{C}\right)$ dibandingkan dengan di Kecamatan Kumelembuai yang memiliki temperatur lingkungan rata-rata $\left(22,0^{\circ} \mathrm{C}\right)$, dimana suhu yang tinggi akan menyebabkan terjadinya avapotranspirasi sehingga prosentase kadar air pada jerami jagung menurun akibat tanaman cenderung dehidrasi dan mengakibatkan bobot jerami jagung pada dataran rendah lebih rendah dibandingkan dengan bobot jerami jagung pada dataran tinggi yang pemotongannya dilakukan secara bersamaan.

Menurut Kartasapoetra (2006) bahwa suhu lingkungan yang tinggi akan mempengaruhi kandungan air daun dan daun akan mengalami defisit air. Hal ini sesuai dengan pengamatan pada saat pengambilan sampel jerami jagung di dataran rendah lebih cepat mengalami penuaan/mengering dibanding dataran tinggi, sehingga bobot jerami jagung pada dataran rendah lebih rendah dibandingkan dengan bobot jerami jagung pada dataran tinggi dengan umur tanam yang sama.

Faktor curah hujan juga sangat mempengaruhi rendahnya produksi jerami jagung di Kecamatan Amurang Barat, dimana curah hujan rata-rata yang terjadi selama pengamatan 114.48 $\mathrm{mm}$ per bulan. Sutoro $d k k$ (1998) menyatakan bahwa curah hujan yang normal untuk pertumbuhan tanaman jagung adalah 200 - 250 $\mathrm{mm}$ per bulan. Curah hujan di Kecamatan Kumelembuai masih sesuai dengan pendapat tersebut yaitu 220,79 $\mathrm{mm}$ per bulan.

Produksi bahan kering tergantung pada ketersediaan unsur hara dalam tanah. Kendatipun pada kedua lokasi penelitian diberikan juga pupuk yang sama, tetapi efektifitas penggunaannya turut dipengaruhi oleh kehidupan mikroba pada lingkungan risorfer perakaran tanaman. Hal ini sejalan dengan pendapat Kuzyakov (2002) yang menyatakan bahwa tanah yang cukup lembab dan tidak kering mikroorganisme tanah tumbuh dan berfungsi dengan baik, untuk membantu proses penyediaan dan penyerapan unsur hara. Aktifitas mikroba tanah pada lingkungan tanah yang lembab dan tidak kering terjadi proses mineralisasi nitrogen lebih baik.

\section{Protein Kasar, NDF dan ADF}

Data hasil kandungan Protein Kasar, NDF dan ADF jerami jagung dari kedua lokasi penelitian disajikan pada Tabel 2.

\section{Kandungan Protein Kasar}

Tabel 2 dapat dilihat bahwa rataan kandungan protein kasar di kecamatan Amurang Barat sebesar $6,51 \%$ yang nyata $(P<0,01)$ lebih rendah dibanding dengan rataan kandungan protein kasar jerami jagung di Kecamatan Kumelembuai sebesar 8,19\%. Rendahnya protein jerami jagung di kecamatan Amurang Barat yang letaknya di dataran rendah terkait dengan suhu lingkungan yang relatif lebih tinggi $\left(25,4^{\circ} \mathrm{C}\right)$ dibandingkan dengan di Kecamatan Kumelembuai yang memilik temperatur lingkungan rata-rata $\left(22,0^{\circ} \mathrm{C}\right)$, dimana suhu yang tinggi akan menyebabkan terjadinya avapotranspirasi sehingga prosentase kadar air pada jerami jagung menurun akibat tanaman cenderung dehidrasi sehingga proses pengeringan dan penuaan tanaman lebih cepat terjadi. Hal ini sejalan dengan pendapat Tjitrosoepomo (1989) bahwa penuaan daun melibatkan penguraian klorofil dan protein-protein kemudian produk tersebut diangkut oleh floem ke jaringan maristem atau bagian lain tanaman yang membutuhkannya. Hal ini menyebabkan kadar protein pada jerami jagung yang mengalami penuaan akan berkurang.

Rataan kandungan protein kasar kedua Kecamatan tersebut ternyata masih lebih tinggi dibanding dengan rataan dari beberapa daerah $\mathrm{di}$ Indonesia sebesar 5,56\% (Umiyasih dan Wina, 2008), tetapi untuk rataan Kecamatan Kumelembuai sedikit lebih rendah bila dibandingkan dengan yang dilaporkan oleh Preston (2006) yaitu sebesar $9 \%$, sedangkan untuk rataan Kecamatan Amurang Barat jauh lebih rendah sebab hanya $6,51 \%$. 
Tabel 2. Kandungan Protein Kasar, NDF dan ADF Jerami Jagung di Kecamatan Amurang Barat dan Kecamatan Kumelembuai

(Table 2. Crude Protein Content, NDF and ADF in Corn Straw Western District and District Amurang Kumelembuai)

\begin{tabular}{|c|c|c|c|c|c|c|c|c|c|}
\hline \multirow[b]{2}{*}{ No. } & \multirow[b]{2}{*}{$\begin{array}{l}\text { Lokasi } \\
\text { (Desa) }\end{array}$} & \multicolumn{3}{|c|}{ Kec. Amurang Barat } & \multirow[b]{2}{*}{ No. } & \multirow[b]{2}{*}{$\begin{array}{l}\text { Lokasi } \\
\text { (Desa) }\end{array}$} & \multicolumn{3}{|c|}{ Kec. Kumelembuai } \\
\hline & & $\begin{array}{l}\text { PK } \\
(\%)\end{array}$ & $\begin{array}{l}\text { NDF } \\
(\%)\end{array}$ & $\begin{array}{l}\text { ADF } \\
(\%)\end{array}$ & & & $\begin{array}{l}\text { PK } \\
(\%)\end{array}$ & $\begin{array}{l}\text { NDF } \\
(\%)\end{array}$ & $\begin{array}{l}\text { ADF } \\
(\%)\end{array}$ \\
\hline 1. & Teep & 7,35 & 46,45 & 30,50 & 1. & Kumelembuai & 8,33 & 43,19 & 28,90 \\
\hline 2. & Kapitu & 5,87 & 47,72 & 31,22 & 2. & Kumelembuai Atas & 8,27 & 45,56 & 29.28 \\
\hline 3. & $\begin{array}{l}\text { Kawangkoan } \\
\text { Bawah }\end{array}$ & 6,32 & 45,42 & 31,50 & 3. & Kumelembuai Dua & 7,66 & 45,45 & 29,42 \\
\hline $\bar{x}$ & & 6,51 & 46,55 & 31,07 & $\bar{x}$ & & 8,19 & 44,73 & 29,20 \\
\hline
\end{tabular}

Ditinjau dari aspek nutrisi dan makanan ternak rataan kandungan protein kasar di Kecamatan Amurang Barat dapat mencukupi kebutuhan sapi daging akan protein kasar yaitu $5,9 \%$ (NRC, 1996) tetapi tidak cukup untuk memenuhi kebutuhan sapi perah laktasi sebesar 9,2\% (NRC,1996) dan untuk kebutuhan minimal secara umum ternak ruminansia yaitu sebesar $8 \%$ (Coleman et.al., 2003). Pemberian silase jerami jagung pada sapi potong memberikan performans reproduksi yang tidak berbeda nyata bila menggunakan suplemen kosentrat jagung dan bungkil kedele (Howlett et.al., 2003).

\section{Kandungan NDF dan ADF}

Tabel 2 menunjukkan bahwa rataan kandungan NDF jerami jagung di Kecamatan Amurang Barat dan Kecamatan Kumelembuai berturut-turut $46,55 \%$ dan $44,73 \%$. Hasil analisis uji t menunjukkan bahwa terdapat perbedaan yang sangat nyata $(P<0,01)$ antara kandungan NDF jerami jagung di daerah dataran rendah dan daerah dataran tinggi, dimana di daerah dataran rendah kandungan NDFnya lebih tinggi dari pada di daerah dataran tinggi. Tabel 3 juga menunjukan bahwa rataan kandungan ADF di Kecamatan Amurang Barat dan Kecamatan Kumelembuai berturut-turut $31,07 \%$ dan $29,20 \%$. Hasil analisis uji t menunjukkan bahwa terdapat perbedaan yang sangat nyata $(P<0,01)$ antara kandungan ADF jerami jagung di daerah dataran rendah dan daerah dataran tinggi, dimana di daerah dataran rendah kandungan
ADFnya lebih tinggi dari pada di daerah dataran tinggi.

Lebih tingginya kandungan NDF dan ADF jerami jagung di dataran rendah dibanding dengan dataran tinggi disebabkan karena jerami jagung di dataran rendah lebih cepat mengalami penuaan. Menurut Iriany $d k k$ (2008) bahwa umur panen jagung sangat dipengaruhi oleh suhu, setiap kenaikan tinggi tempat $50 \mathrm{~m}$ dari permukaan laut.

\section{KESIMPULAN DAN SARAN}

\section{Kesimpulan}

Produktivitas jerami jagung di dataran tinggi (Kecamatan Kumelembuai) lebih tinggi dari pada di dataran rendah (Kecamatan Amurang Barat), dimana rataan produktivitas bahan kering jerami jagung di Kecamatan Kumelembuai mencapai $1873 \mathrm{~kg} \mathrm{ha}{ }^{1}$, sedangkan di Kecamatan Amurang Barat $1475 \mathrm{Kg}$ ha ${ }^{1}$, meskipun dari segi penyediaan energy (TDN) Kecamatan Amurang Barat (1405,0 UT) lebih tinggi dibanding Kecamatan Kumelembuai (559,2 UT) oleh karena Kecamatan Amurang Barat memiliki luas lahan lebih besar dibanding Kecamatan Kumelembuai.

Kandungan protein jerami jagung di dataran tinggi (Kecamatan Kumelembuai) lebih tinggi dari pada di dataran rendah (Kecamatan Amurang Barat).

Kandungan ADF, dan NDF jerami jagung di dataran rendah (Kecamatan Amurang Barat). lebih tinggi dari pada di dataran tinggi (Kecamatan Kumelembuai). 


\section{Saran}

Perlu dilakukan penelitian lanjutan dengan menggunakan ternak sapi agar diketahui pengaruh kualitas jerami jagung terhadap performans ternak sapi.

\section{DAFTAR PUSTAKA}

Badan Pusat Statistik dan Departemen Pertanian RI. 2007. Pengumpulan Data Tanaman Pangan. Buku Pedoman Badan Pusat Statistik dan Departemen Pertanian RI, Jakarta.

Coleman, S.W., S.P. Hart and T. Sahlu. 2003. Ralation Among Forege Chemistry, Rumination and Retention Time with in the and Digestibility of hay by Goats. Small Rum. Res 50: 129-140.

Howlett, C.M., E.S. Vanzant, L.H. Anderson and R.F. Bapst. 2003. Efects of Supplemental Nutrient Source on Reiter Growth and Reproduction Performance, and on Utilization of Corn Silase-based Diets by Beef Aters. J. Amin. Sci. 81: 2367-2378.

Iriany, R.M., H.G. Yasin dan A.M. Takdir. 2008. Asal Sejarah Taksonomi Tanaman Jagung. Jurnal ilmiah Balai Penelitian Tanaman Serealia, Maros. Hal 1-12.
Kartasapoetra, A.G. 2006. Klimatologi Pengaruh Iklim Terhadap Tanah dan Tanaman. Penerbit PT Bumi Aksara. Jakarta.

Kuzyakov, Y. 2002. Factor Effecting Rhizophere Priming Effects. J Plant dlut Soil Sci 165 : 382-396.

NRC. 1976. Nutrient Requirment of beef cattle. Fifth revised. NAS, Washington DC.

Preston, R.L. 2006. Feed Composition Tables. http://beff-mag.com/mag/beef.feed Composition.

Sutoro, Y. Sulaeman, dan Iskandar. 1998. Budidaya Tanaman Jagung. Badan Penelitian dan Pengembangan Pertanian. Pusat Penelitian dan Pengembangan Tanaman Pangan. Bogor.

Tjitrosoepomo, G. 1989. Taksonomi Tumbuhan. Universitas Gadjah Mada Press. Yogyakarta.

Umiyasih, U dan E. Wina. 2008. Pengolahan Nilai Nutrisi Limbah Jagung sebagai Pakan Ternak Ruminansia. Wartazoa 18 (3): 127136. 